\title{
The pavilions of Expo 2015 in Milan, as a privileged observatory about the concept of sustainable construction in all languages of the world
}

\author{
Alberto La Tegola*, Fabio Longo, and Andrea Lanzilotti \\ Department of Innovation Engineering, University of Salento, Lecce, Italy
}

Received: 23 March 2016 / Accepted: 26 January 2019

\begin{abstract}
The organization of Expo 2015 in the city of Milan has prompted massive organizational efforts to set up a new fair district in one of the largest Italian cities. The urban layout of the metropolitan city has been redesigned in order to accommodate all participating nations event. Expo 2015 established through guidelines the necessity to adopt sustainable solutions for the temporary buildings of the exhibition. The article aims to see how the concepts of sustainability and recyclability have been interpreted in the language of 40 designers from different countries. Through data provided by information papers of the exhibition, a valuation of materials used in buildings was made. This research led to an analysis of different building typology involved and the materials most used to reach the goals of guidelines drawn up by Expo 2015. The perception of an event characterized by green constructions was achieved, but not every construction was aimed to be a nearly zero emission building.
\end{abstract}

Keywords: holistic concept of sustainability in architecture / Expo 2015 / eco-sustainable materials and building technologies / eco-sustainable concept / temporary buildings

\section{Introduction}

The great expositions have always been characterized by new architectures and technologies. "Feeding the planet, energy for life" is the main theme of Milano Expo 2015 and the organization encouraged the participants to join the topic in every aspect of the event, even in the design of the pavilions. The energy for life represents one of the most discussed topics of this century since, as Global Footprint stated, we are in a global ecological overshoot. In other words, we are using more resources than the earth can provide, and new environmental approaches to the use of energy resources represents one of the most critical challenges to face in this century.

To ensure the effort of all participants to adopt ecosustainable measures, Milano Expo 2015 established a series of environmental criteria collected in some guidelines. The "green procurement guidelines" [1], for example, offer some criteria that permit to make the sustainability "not just an objective but part of the event itself." All these criteria are based on services and technologies already available in Europe, such as food recovery, use of renewable materials, waste recovery, etc. In addition, the guidelines

\footnotetext{
* e-mail: alberto.lategola@unisalento.it
}

suggest some tips to integrate the environmental criteria in the phase of the contractor awarding process (e.g., environmental goals in the contract, selection of candidates with environmental certifications, or certifications in materials quality and production).

In this scenario, sustainable buildings could be the key to face the problem of energy consumption, since the building sector is responsible for the $40 \%$ of the world's energy consumption itself. For this reason, the construction of sustainable pavilions has been considered one of the most important starting points of the exhibition.

The document "Guidelines Sustainable Solutions" [2] lists the solutions, which are organized in four sections representing the three phases of the work that will be done on the pavilions: design, construction, dismantling, and reuse. Each participant may adopt voluntarily one or more solutions, depending on its strategy for the exhibition plan, architectural language, technology know-how, and culture.

This research is aimed to analyze how different designers from different countries conceive the concept of sustainability and how they apply the architectural state-of-art of their nation to reach the goals established in the guidelines. Therefore, the first part of the paper deals with the holistic conception of architecture and the review of the technological solutions adopted during the construction phase of Expo 2015, while the second part is the 
analysis of the quantities as a mean to establish the impact of the pavilions and how much sustainability guidelines have been followed.

\section{Background}

In the last two decades, issues linked to pollution, climate changes, and natural disasters focused the attention on the meaning of the word "sustainable" [3]. Since the building industry is a major cause of pollution, designers are called to use knowledge and technology to reduce the demand for energy of building systems. For this reason, the definitions of "green building" and "sustainable architecture" are strictly linked to the new design strategy and to the technology that will be adopted in the coming years [4].

Expo 2015 represented a big chance to implement new building technologies and to propose a new concept of "green building." The attention to the architectures of the expositions is always high [5], and how different nations interpreted the challenge in green building design is surely a theme of interest in the literature [6].

\section{Guidelines sustainable solutions}

The aim of sustainable solutions is to reach building comfort using as few resources as possible and ensuring the resources themselves are ecological, renewable, and workable with low-energy emissions.

The first section of the guidelines sets the design criteria. This part deals with the functional layout and the technologies used to provide thermal inertia, reduce overheating, improve day-lighting, and maximize the use of alternative energy. The period of the exhibition is from May to October, so the biggest challenge to face is the minimization of the demand for cooling. The employed layout must provide thermal inertia, natural ventilation, shadows (but also day-lighting), and, if necessary, smart control systems.

The second section deals with design materials and construction technologies. The material should be natural, renewable, locally available, nontoxic, and with minimal chemical emission. Sometimes, the adoption of an alternative green material is easier than what it seems, because a traditional material like masonry can be swapped with a block made from glued board offcuts of softwood or a panel with preselected waste. Other interesting solutions are offered by materials like bamboo (one of the strongest plant-based building material), laminates, wood plastic composite, and ceiling tiles. Construction technology management requires the attention to some simple and well-known aspects as salvaging materials, reducing waste production, adopting prefabricated elements, using natural surface, and reducing off-cutting on site.

The third section contains the principle useful to plan the dismantling and reusing of the pavilions. The simple principle is to minimize the landfill waste, design the structures for deconstruction, and dismantle without demolition. It is essential to choose a resistant and durable material; after that the structures must be designed in order to be easily disassembled and moved away.

\section{Research methodology}

Research was carried out for collecting all data available for each of the 40 pavilions listed in Table 1. These pavilions are not all the structures of the exhibition, but they represent $75 \%$ of participating nations, and the area they occupy is $71 \%$ of exhibition total area.

Data about structures, claddings, area assigned, and area built for each nation are available on the information papers of the exposition, on the site of the event, and on the sites of every participant. If no data are available, an estimation is made, thanks to the plans and the representations of the structures.

Through the collected data, an analysis concerning the materials used in the different pavilions was performed in order to understand which materials and building technologies were considered, the most suitable to reach the goals of the guidelines by the different designers.

\section{Architecture of national pavilions}

As already mentioned, all nations listed in Table 1 are required to build a temporary building for Expo 2015, which is going to last from May to October 2015. At the end of the event, constructions must be dismantled and moved away in 6 months. This request is surely the reason why the most important aspect in designing is to ensure an easy construction and a fast dismantling. Palazzo Italia represents an exception: This construction with the tree of life is going to remain on the site, so they are designed to be permanently where they actually are.

Regardless of this issue, this section's goal is to observe how nations interpreted the guidelines and what they preferred to communicate through the pavilion. In fact, some nations used the pavilion to evocate the theme of Expo, others preferred to evocate their national symbols, developing the architectural elements that show a specific know-how or building technology.

Italian pavilion included Palazzo Italia (Fig. 1) and a series of temporary buildings onto the Cardo. This construction was the occasion to develop the theme of sustainability through a new technology: The external façade of Palazzo Italia was composed of 900 biodynamic concrete panels with TX Active Technology (Italcementi's patent). This dynamic material permits the creation of complex shapes and helps in air pollution reduction. Furthermore, it is made of $80 \%$ recycled aggregates (marble, cement).

The Japanese pavilion represented another symbolic architecture, since it provided, as shown in Figure 2, a three-dimensional self-supporting façade made out of laminated wood with a technique typical of Japanese building culture. This construction embedded simple elements in a complex grid made using a "compressive strain method," in which joints consist only of carved wood, without metal couplers, for support. Japanese designers have been able to fuse the ancient techniques of their tradition with the technology to reach the goal of sustainability. In fact, the elements of the façade helped maintain the comfort, generating a shaded environment with natural daylight. 
Table 1. Exposition area, building area, structure type and cladding type of the examined pavilions.

\begin{tabular}{|c|c|c|c|c|c|c|}
\hline \multirow{2}{*}{\multicolumn{2}{|c|}{ Nation }} & \multirow[b]{2}{*}{ Exposition Area $\left[\mathrm{m}^{2}\right]$} & \multirow[b]{2}{*}{ Building Area $\left[\mathrm{m}^{2}\right]$} & \multirow[b]{2}{*}{$\%$ Coverage } & Structure & \multirow{2}{*}{$\begin{array}{l}\text { Cladding } \\
\text { Material }\end{array}$} \\
\hline & & & & & Type & \\
\hline 1 & Angola & 2.010 & 1.280 & $63,68 \%$ & Wood-Steel Frame & Wood \\
\hline 2 & Argentina & 1.907 & 950 & $49,82 \%$ & Steel Frame & $\begin{array}{l}\text { Steel } \\
\text { Plastic }\end{array}$ \\
\hline 3 & Austria & 1.910 & 1.000 & $52,36 \%$ & Wood Frame & $\begin{array}{l}\text { Wood } \\
\text { Plastic }\end{array}$ \\
\hline 4 & Azerbaijan & 887 & \multirow[t]{2}{*}{500} & $56,37 \%$ & Wood-Steel Frame & $\begin{array}{l}\text { Wood } \\
\text { Glass }\end{array}$ \\
\hline 5 & Bahrain & 2.010 & & & Reinforced Concrete Frame & Concrete \\
\hline 6 & Belarus & 1.147 & 500 & $43,59 \%$ & Steel Frame & Wood \\
\hline 7 & Belgium & 3.604 & 750 & $20,81 \%$ & Wood-Steel Frame & $\begin{array}{c}\text { Glass } \\
\text { Wood } \\
\text { Rockwool }\end{array}$ \\
\hline 8 & Brazil & 4.133 & 2.385 & $57,71 \%$ & Steel Frame & Cork \\
\hline 9 & Chile & 1.910 & 975 & $51,05 \%$ & Wood-Steel Frame & $\begin{array}{l}\text { Wood } \\
\text { Glass }\end{array}$ \\
\hline 10 & China & 4.590 & 2.500 & $54,47 \%$ & Wood-Steel Frame & $\begin{array}{l}\text { Wood } \\
\text { Bambù } \\
\text { Plastic }\end{array}$ \\
\hline 11 & Colombia & 1.907 & 907 & $47,56 \%$ & Wood Frame & wood \\
\hline 12 & Czech Republic & 1.362 & 340 & $24,96 \%$ & Steel Frame & $\begin{array}{l}\text { Glass } \\
\text { Aluminium } \\
\end{array}$ \\
\hline 13 & Ecuador & 747 & 400 & $53,55 \%$ & Steel Frame & $\begin{array}{l}\text { Aluminium } \\
\text { Plastic }\end{array}$ \\
\hline 14 & France & 3.592 & 2.000 & $55,68 \%$ & Wood Frame & Wood \\
\hline 15 & Germany & 4.913 & 2.680 & $54,55 \%$ & Steel Frame & $\begin{array}{l}\text { Plastic } \\
\text { Wood }\end{array}$ \\
\hline 16 & Hungary & 1.910 & 1.530 & $80,10 \%$ & Wood-Steel Frame & Wood \\
\hline 17 & Indonesia & 1.175 & 560 & $47,66 \%$ & Steel Frame & $\begin{array}{l}\text { Plastic } \\
\text { Bambù }\end{array}$ \\
\hline 18 & Ireland & 1.175 & 300 & $25,53 \%$ & X-Lam & $\begin{array}{l}\text { Wood } \\
\text { Plastic }\end{array}$ \\
\hline 19 & Israel & 2.370 & 995 & $41,98 \%$ & Stell Frame & $\begin{array}{l}\text { Wood } \\
\text { Plastic }\end{array}$ \\
\hline 20 & Italy & 13.275 & 3.306 & $24,90 \%$ & Steel Frame & $\frac{\text { Biodynamic Concrete }}{\text { Glass }}$ \\
\hline 21 & Japan & 4.170 & 2.000 & $47,96 \%$ & Steel Frame & Wood \\
\hline 22 & Kuwait & 2.170 & 12000 & $43,001 \%$ & Steel Erame & $\begin{array}{l}\text { Glass } \\
\text { pyc }\end{array}$ \\
\hline 23 & Lithuania & 1.147 & 950 & $82,82 \%$ & Steel Frame & Plastic \\
\hline & & & & & & Steel \\
\hline 24 & Malaysia & 2.047 & 1.200 & $58,62 \%$ & Wood Frame & $\begin{array}{l}\text { Wood } \\
\text { Plastic }\end{array}$ \\
\hline 25 & Marocco & 2.898 & 1.300 & $44,86 \%$ & Wood Frame & Wood \\
\hline 26 & Moldova & 747 & 250 & $33,47 \%$ & Steel Frame & Glass \\
\hline 27 & Netherlands & 2.369 & 1.080 & $45,59 \%$ & Steel Frame & $\begin{array}{l}\text { Plastic } \\
\text { Glass }\end{array}$ \\
\hline 28 & Principality of Monaco & 1.010 & 360 & $35,64 \%$ & Wood-Steel Frame & Wood \\
\hline 29 & Qatar & 2.450 & 1.200 & $48,98 \%$ & Concrete Frame & $\begin{array}{c}\text { Concrete } \\
\text { Plastic } \\
\text { Wood } \\
\end{array}$ \\
\hline 30 & Republic of Korea & 3.880 & 2.400 & $61,86 \%$ & Steel Frame & Wood \\
\hline 31 & Russia & 4.170 & 1.730 & $41,49 \%$ & Wood-Steel Frame & Wood \\
\hline 32 & Slovakia & 1.010 & 385 & $38,12 \%$ & Steel Frame & $\begin{array}{l}\text { Glass } \\
\text { Wood }\end{array}$ \\
\hline 33 & Slovenia & 1.910 & 870 & $45,55 \%$ & Stell Frame & $\begin{array}{l}\text { Wood } \\
\text { Glass }\end{array}$ \\
\hline 34 & Spain & 2.533 & 1.300 & $51,32 \%$ & Wood-Steel Frame & Wood \\
\hline 35 & Switzerland & 4.432 & 200 & $4,51 \%$ & Steel Frame & $\begin{array}{l}\text { Glass } \\
\text { Glass }\end{array}$ \\
\hline 36 & United Emirates & 4.386 & 1.175 & $26,79 \%$ & Steel Frame & GRC \\
\hline 37 & United Kingdom & 1.910 & 970 & $50,79 \%$ & Steel Frame & \\
\hline 38 & United States of America & 2.790 & 900 & $32,26 \%$ & Steel Frame & $\begin{array}{l}\text { Glass } \\
\text { Wood }\end{array}$ \\
\hline 39 & Vietnam & 887 & 430 & $48,48 \%$ & Steel Frame & Bambù \\
\hline & & & & & & $\begin{array}{l}\text { Glass } \\
\text { Wood }\end{array}$ \\
\hline 40 & Thailand & 2.947 & 1.200 & $40,72 \%$ & Wood-Steel Frame & Plastic \\
\hline & Total & 107.017 & 44.958 & $45,88 \%$ & & \\
\hline
\end{tabular}




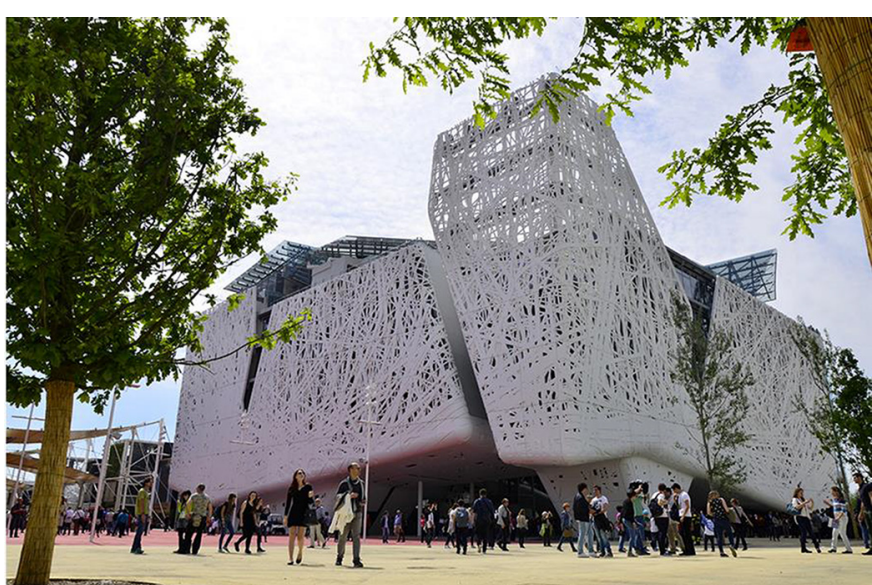

Fig. 1. Palazzo Italia (expo2015.org).

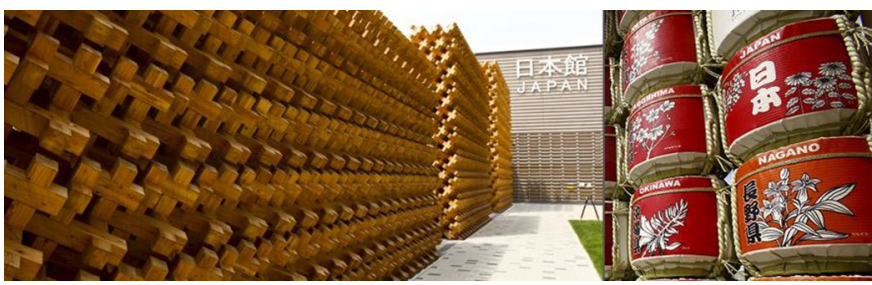

Fig. 2. Details of Japanese façade (expo2015.org).

Another interesting technological solution was adopted in the roof of Chinese pavilion. The structure of the roof was composed of laminated wooden beams joined with steel elements. A complex work was made to design a roof so big, and six steel beams were added to increase the stiffness of the construction. Furthermore, the roof was covered by a layout made of translucent textile membranes and bamboo panels. The texture of this layout was designed to make the daylight pass, ensuring a cool environment in the hottest days. The shape of the building was designed to permit the reinstallation of the pavilion on an already chosen site in China. Due to the materials and the techniques employed in the building, the Chinese pavilion was one of the most interesting architectural and engineering attractions of the exhibition.

Even Russian designers worried about the reinstallation of the pavilion in their nation. In fact, the most impressive element of the pavilion was surely the 30-m-long cantilever, which was a metaphor referencing the soft lines of the Russian landscape. Russia also tried to respect all the way the sustainability guidelines, improving a structure of steel beams covered by different types of wood. Wood was the principal cladding element: floor and insulation elements were of wood and the façade was in Oak Lamella.

Bamboo represented an interesting new cladding solution. As already mentioned, Chinese designers adopted bamboo panels for the roof, but also Indonesian pavilion was made with a massive use of this material. The most interesting use of bamboo was shown in the pavilion of Vietnam: In this building, water was the main theme, and that is why lotus flowers were built. The lotus pods were made of a steel frame surrounded and lined with bamboo (see Fig. 3); the plant is a typical symbol of Vietnam.

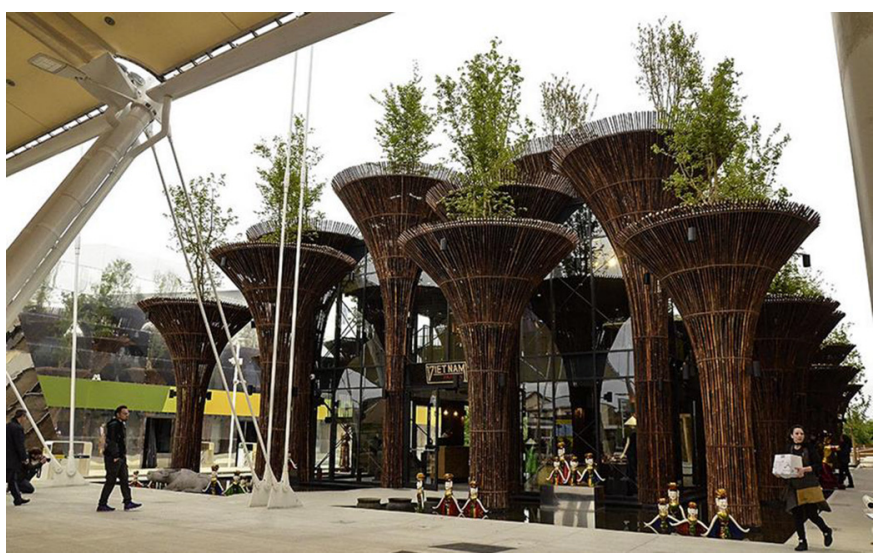

Fig. 3. Vietnam pavilion (expo2015.org).

The Austrian pavilion focused on the country's natural and technological expertise, since it is a forest planted on the Expo site. The structure was very simple: the perimeter was enclosed by $180 \mathrm{~m}$ of $6 \mathrm{~m}$-high plywood walls. For sure, a girder wood system helped in the loads support and some plastic materials were used to improve the insulation power. The principal theme of the Austrian exposition was the breath: The forest produces oxygen and absorbs $\mathrm{CO}_{2}$. Moreover, it guarantees the production of cool air, thanks to evapotranspiration of the plants. This is how the theme of sustainability and environment protection has been developed.

The aim of the United Kingdom was to raise global awareness and stimulate discussion about the impact of food production and consumption. The pavilion represented a big beehive, one of the most important natural elements in agriculture. The beehive has been machined and fabricated in York with 169,300 aluminum and steel components, assembled in 32 horizontal layers. LED light fittings into aluminum node components glow and pulsate to represent the activity of a real beehive.

Some nations have considered mainly the development of the theme through architecture. The United States and Israel, as shown in Figure 4, built a vertical green field. The Israeli pavilion had a green wall $70 \mathrm{~m}$ long and $12 \mathrm{~m}$ high made of modular tiles for cultivating crops supported by a steel frame elevated above the ground. The field was irrigated by an electronic system and this was one of the many innovations in the field of agricultural techniques shown in the pavilion. The distinguishing feature of the US pavilion was the presence in the long side façade of a vertical farm that had been harvested every day.

The French building was inspired by the traditional indoor market, symbol of the alimentary culture of France, and it featured a reversed landscape: a landscaped roof covering a huge space supported by several giant pillars. The pavilion was entirely realized with French wood: The load-bearing structure was made of laminated wood, a reticular system of curved beams, and was cladded with larch wood.

The entire Czech Republican project was based on water, the main theme of the exhibition and the element that shaped the country's regions and cities. The building 


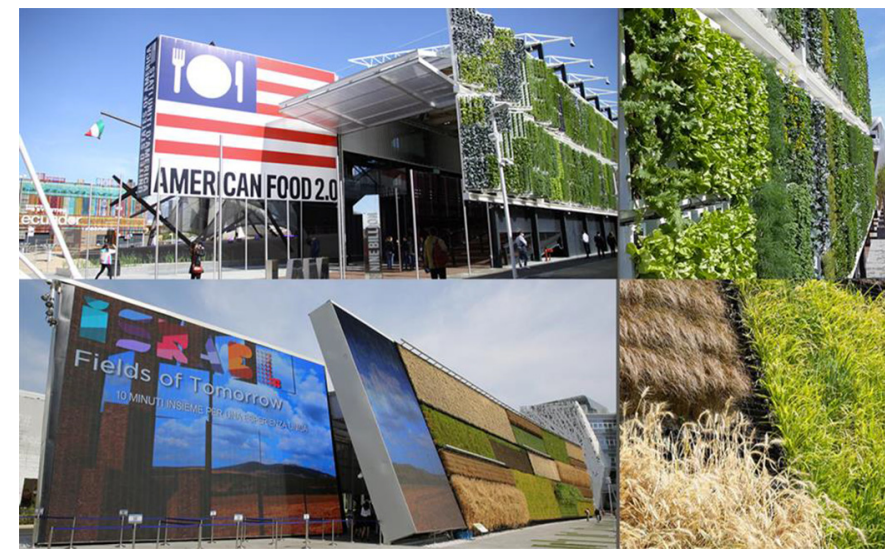

Fig. 4. US and Israel pavilions (expo2015.org).

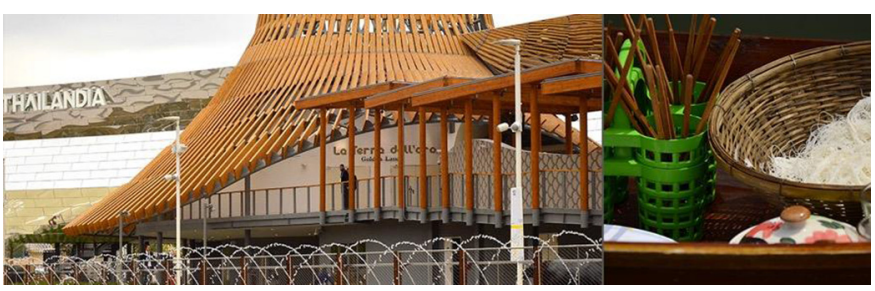

Fig. 5. Thailand pavilion (expo2015.org).

was made out of modular $3 \times 3$ and $3 \times 9 \mathrm{~m}$ sections composed of zinc-plated steel frame, covered with aluminum and glass. There was a garden on the roof and a pool outside the pavilion. The modular steel architecture employed was minimal and simple, and so it made the construction of the easiest to build and dismount.

The first example of a pavilion representing a national symbol was the Thailand pavilion: It is inspired by the "Ngob," the rice farmers' traditional hat, which has been used since ancient times, symbolizing an understanding of the land and local wisdom (see Fig. 5).

The UAE pavilion was a reference to the dunes, since the most evident elements were the walls that seemed to be made of sand. The functional layout was designed to act well in Milano and in the Emirates; moreover, a rainwater harvesting system and a photovoltaic system were present. Due to these reasons and to the transport of materials by zeroemission means, the project received a gold LEED certificate.

The choice of Chile designers was also interesting, since the pavilion looked like a massive wooden bridge, inspired by the traditional roofed bridges that offered shelter from rain. The suspended structure was a frame of crosslaminated wooden beams supported by six steel pillars, and the wood used had been shipped from Chile and laminated in Italy.

The architecture of Morocco's pavilion was one of the most distinctive and represented all the diversity of the country. The pavilion was a Kasbah, the symbol that characterizes the architectural style of Southern Morocco. The materials employed were wood and clay. Morocco has a long tradition in architecture that faces the challenge of hot climate; the pavilion was a simple transposition of this Millenary know-how.

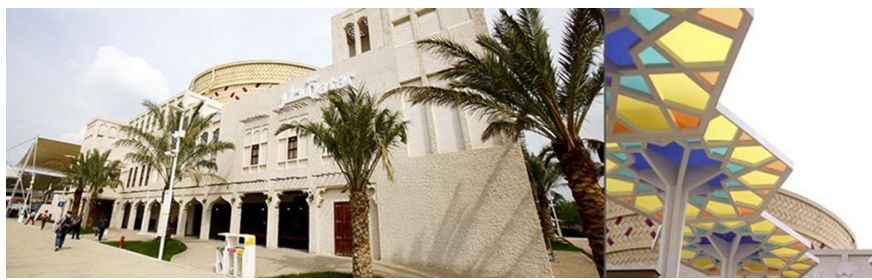

Fig. 6. Qatar pavilion (expo2015.org).

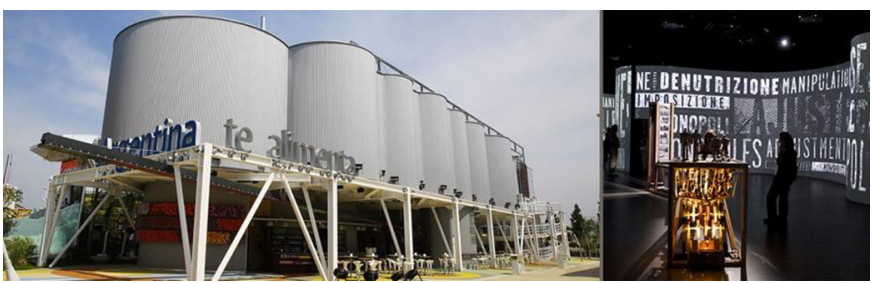

Fig. 7. Argentina pavilion (expo2015.org).

The Qatar pavilion (Fig. 6) evocated the traditional Arabian market: On a large central space, a circular structure soared, symbolizing a traditional food basket. The central body was realized with steel elements, while the other parts were prefabricated columns and beams.

Brazilian designers decided to promote the great agroindustrial activity of the nation along with the architecture of the pavilion. The structure appeared as a big factory with a net that invited visitors to venture into the heart of the pavilion. A big girder system of corten steel formed a closed volume, enclosed by cork slabs.

"Argentina feeds you" is the theme of the South American nation and the will of describing the fertility of its land, which feeds people all over the world through a massive exportation. The theme inspired the design of the pavilion. The construction represented a series of silos joined together, as shown in Figure 7, to show that Argentina is much more than a "repository" of raw materials. The pavilion was built with a steel frame supporting the metallic silos and it looked like an industrial construction. In this way, it is not difficult to dismantle the pavilion and ship structural elements to Argentina.

Mexico built a structure that evocated the most typical Mexican food: corn. The series of overlapping corn husks was made of a core steel structure and a cover in curved PVC membrane, which provided shade while streaming natural light into the interior.

Slovakia is a dynamic country with many natural resources and a great energy potential. These characteristics were evocated by a mill powered by water emerging from the façade. The gears of the mill were made of polycarbonate.

\section{Material quantities analysis}

The structure and cladding type of every pavilion has been already listed in Table 1. As shown in Table 2, the most widespread structure in the exposition was steel frame, followed by wood-steel frame and wood frame. Just two 
Table 2. Structures used in the exhibition.

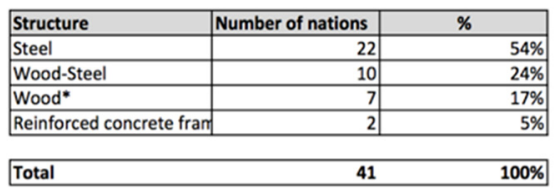

\begin{tabular}{|l|r|}
\hline "X Lam quantity & 1 \\
\hline
\end{tabular}

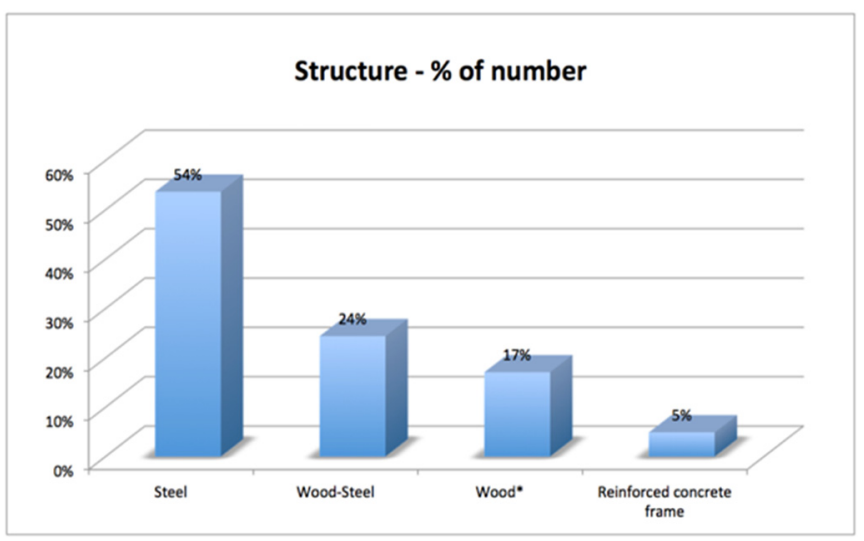

nations adopted concrete frame, probably because it was an easy solution to carry out the project in a fast way with a well-known prefabricated system.

The results of material quantity estimation were reported in Table 3. Data show that $86 \%$ of structural material weight was related to steel, while just $9 \%$ was related to concrete, and $5 \%$ to wood.

Surely, the big percentage of steel was linked to its widespread adoption, but also to the specific weight of the material (the highest among the analyzed materials). It is more interesting to observe that, even if just two structures are made of concrete, $9 \%$ of material weight is of concrete. This is not related just to the specific weight of this material but also to the need of big volumes to ensure the structural safety.

Otherwise, wood is rather widespread, but it represents just $5 \%$ of weight. This means that wood has low specific weight, but also that it ensures a good performance with a small amount of volume.

Data collected in Table 4 revealed a big adoption in weight of artificial material, a strange result if related to a contest where the use of natural material was encouraged all the ways.

A similar analysis was carried out for cladding materials and is reported in Table 5. In this case, more materials have been adopted, but the most used is wood. In fact, wood is a light material with exceptional thermal and acoustic performances. Furthermore, in this case, other interesting solutions were also reported, like bamboo and biodynamic concrete. Bamboo, in particular, is a material that requires little processing and can be easily mounted to make a cover that makes the daylight pass.
Table 3. Quantities percentage of structure weight.

\begin{tabular}{|c|c|c|}
\hline STRUCTURE & \multicolumn{1}{|c|}{$\mathbf{k g}$} & $\mathbf{x}$ \\
\hline Steel & 13.674 .700 & $86 \%$ \\
\hline Wood* & 822.000 & $5 \%$ \\
\hline Concrete & 1.488 .000 & $9 \%$ \\
\hline Totol & 15.984 .700 & $100 \%$ \\
\hline
\end{tabular}
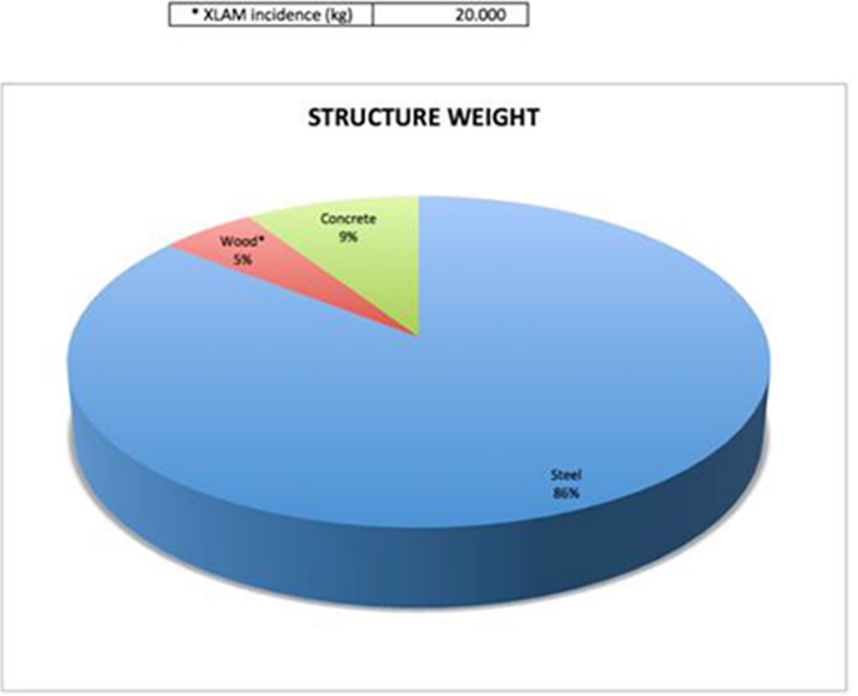

Table 4. Natural materials in structure weight.

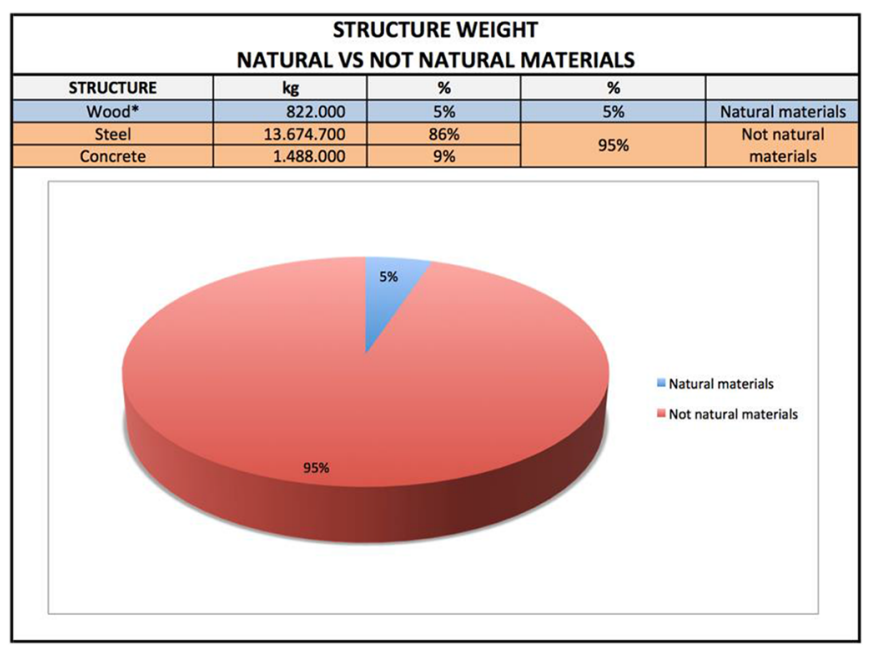

Glass is not a good material to insulate, especially in summertime, but it is widely adopted not only for architectural reasons but also to improve the use of natural light.

Even in this case it was noticeable (Tab. 6) that wood's weight is small in percentage, while glass' weight is higher in percentage, because of its specific weight. 
Table 5. Cladding types used in exhibition.

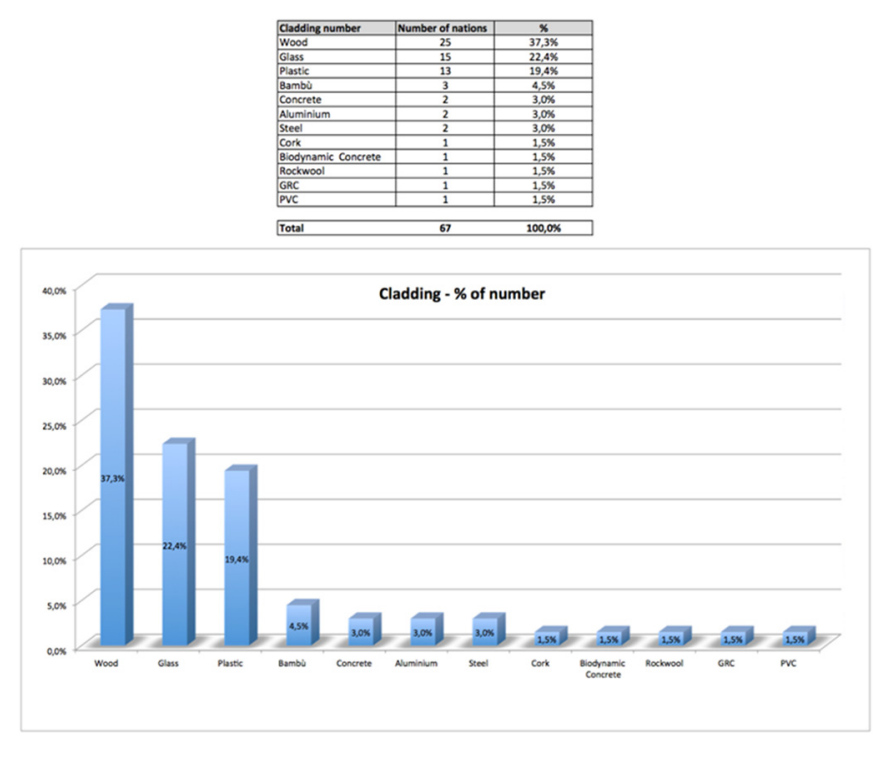

To summarize, the percentage by weight of artificial material is higher than the percentage of natural materials, as shown in Table 7. Despite the contents of the guidelines, the percentage in weight or involved materials highlighted a widespread use of artificial materials.

\section{Reusable materials}

The concept of "reusable material" is controversial and still much discussed [7]. At the end of the cycle of use of a material, the scenery can be very different, depending on the material itself.

Concrete can be recycled, but just an amount of about $20 \%$ and the biggest part (75\%) is "down-cycled" at the end of life into new products. A small amount, equal to $5 \%$, is destined directly to the landfill. There is no way to dismantle and reuse a concrete frame or a part of it; for this reason, this type of material is rarely used in the construction of temporary buildings.

Wood is subject also to some other end-of-life scenarios: It could be incinerated or reused. A big percentage of used wood, equal to $58 \%$, must be moved to a landfill, but the reuse and the recycle process requires a small amount of energy, making wood one of the most suitable material to support sustainability.

Steel can be recycled with a very high percentage (93\%), and a good part of the not-recycled fraction can be reused. In this way, just about $1 \%$ must be moved to the landfill, even if the recycle process requires a lot of energy.

The reuse and recycle processes should reduce or eliminate waste and the request for primary resources. It is possible to obtain these goals with all materials, but while designing a temporary structure is surely attention-worth an analysis of the end-of-life scenarios of materials employed in the project. Depending on the size of structural elements, the architectural boundaries, and
Table 6. Quantities percentage of cladding weight.

\begin{tabular}{|c|r|c|}
\hline CLADDING & \multicolumn{1}{|c|}{$\mathbf{k g}$} & \multicolumn{1}{|c|}{$\boldsymbol{~}$} \\
\hline Wood & 3.804 .500 & $\mathbf{2 2 , 0 5 \%}$ \\
\hline Cork & 6.000 & $0,03 \%$ \\
\hline Bambù & 190.800 & $1,11 \%$ \\
\hline Biodynamic Concrete & 2.000 .000 & $11,59 \%$ \\
\hline Rockwool & 1.000 & $0,01 \%$ \\
\hline Steel & 518.100 & $3,00 \%$ \\
\hline Plastic & 988.880 & $5,73 \%$ \\
\hline Glass & 4.800 .000 & $27,82 \%$ \\
\hline Concrete & 3.024 .000 & $17,53 \%$ \\
\hline Aluminium & 65.000 & $0,38 \%$ \\
\hline GRC & 1.840 .000 & $10,67 \%$ \\
\hline PVC & 14.000 & $0,08 \%$ \\
\hline Total & $\mathbf{1 7 . 2 5 2 . 2 8 0}$ & $\mathbf{1 0 0 , 0 \%}$ \\
\hline
\end{tabular}

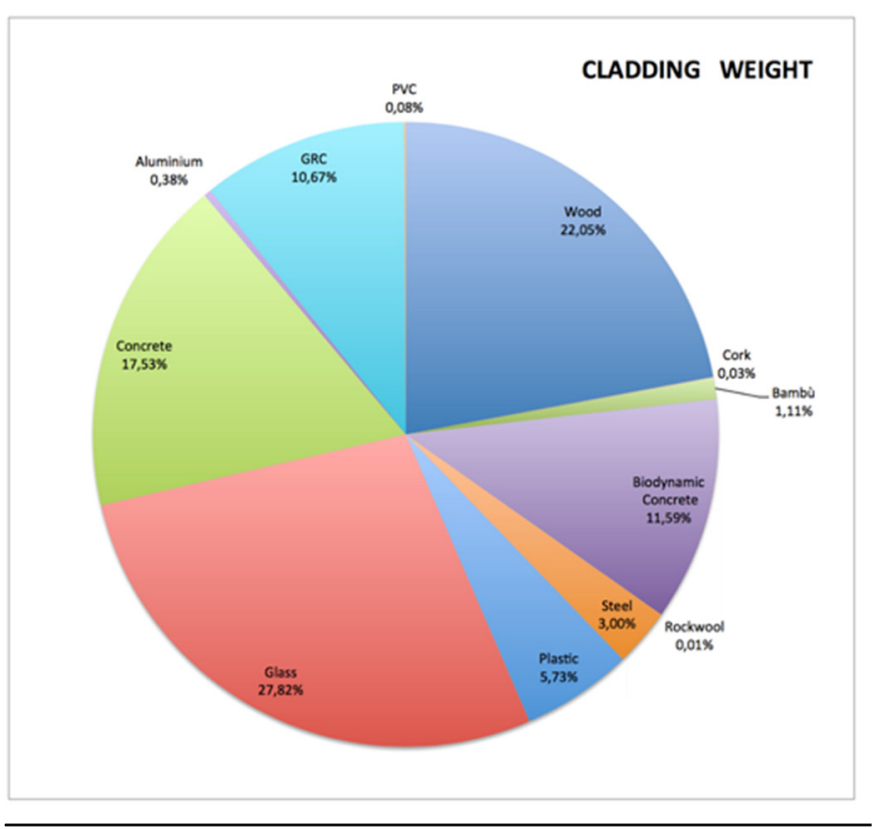

Table 7. Natural materials in cladding weight.

\begin{tabular}{|c|c|c|c|c|}
\hline \multicolumn{5}{|c|}{$\begin{array}{c}\text { CLADDING - \% OF NUMBERS } \\
\text { NATURAL VS NOT NATURAL MATERIALS }\end{array}$} \\
\hline Wood & 25 & $37,3 \%$ & \multirow{3}{*}{$43,3 \%$} & \multirow{3}{*}{ Natural materials } \\
\hline Bambù & 3 & $4,5 \%$ & & \\
\hline Cork & 1 & $1,5 \%$ & & \\
\hline Glass & 15 & $22,4 \%$ & \multirow{9}{*}{$56,7 \%$} & \multirow{9}{*}{$\begin{array}{l}\text { Not natural } \\
\text { materials }\end{array}$} \\
\hline Plastic & 13 & $19,4 \%$ & & \\
\hline Concrete & 2 & $3,0 \%$ & & \\
\hline Aluminium & 2 & $3,0 \%$ & & \\
\hline Steel & 2 & $3,0 \%$ & & \\
\hline Biodynamic Concrete & 1 & $1,5 \%$ & & \\
\hline Rockwool & 1 & $1,5 \%$ & & \\
\hline GRC & 1 & $1,5 \%$ & & \\
\hline PVC & 1 & $1,5 \%$ & & \\
\hline
\end{tabular}

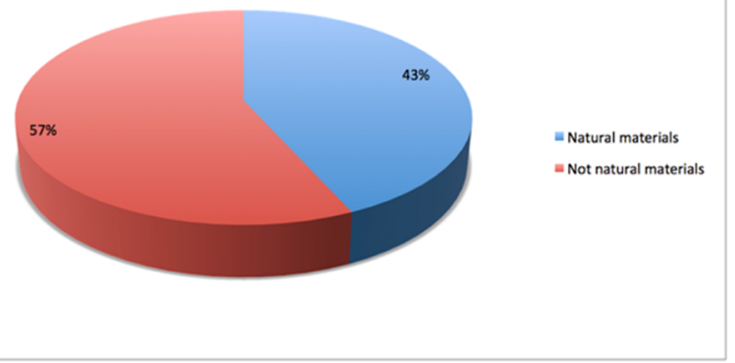


Table 8. End of life scenarios (steelconstruction.info).

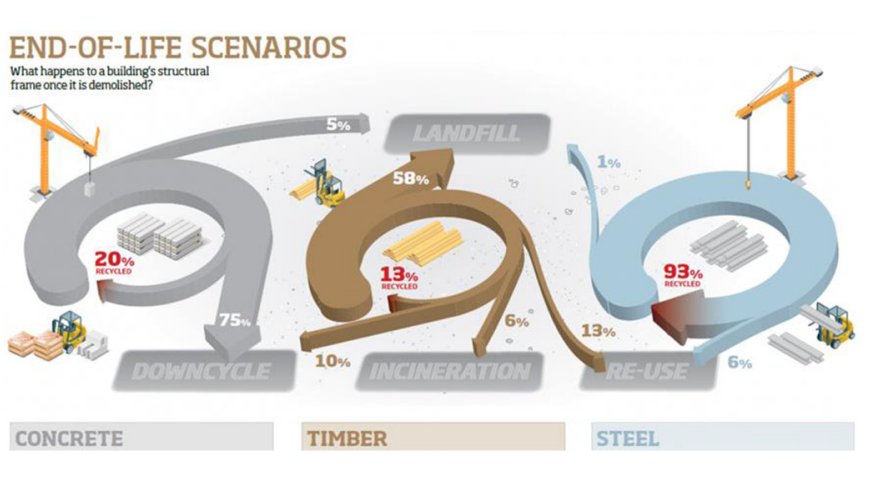

the properties of available materials, a choice must be made: for example, steel is $93 \%$ recyclable, but with a big amount of energy and is very heavyweight, so it represents a suitable and sustainable solution only if the transport request is minimal. Otherwise, wood is recyclable or reusable with a smaller percentage, but if the construction is designed to be easily moved, wood can be the most sustainable choice (Tab. 8).

\section{Conclusions}

As a matter of fact, the exhibition permitted participants to carry out the theme in many ways, not only the architectural one. In other words, there was a container of the theme (the pavilion) and content (everything in the pavilion). Even if the guidelines encouraged the nations to develop the theme through architecture and engineering, it is a choice to focus the majority part of the attention on the container.

As already discussed, the analysis done on the architecture of the pavilions showed that the most used structure was the steel frame, but the main cladding material was wood. Many pavilions were made out with a steel frame - a structure that requires a lot of embodied energy, even if recycled steel is used. The request of the guidelines was to use the state-of-art knowledge to reduce as much as possible the environmental impact of the construction site. Surely, a huge cantilever (e.g., Russian pavilion) requires steel beams to bear loads but probably not all the structures needed the adoption of steel or concrete. It must also be considered that the high specific weight of steel made transportation very expensive. A good solution to respect the exhibition guidelines was to reduce the amount of steel used in the structure (e.g., in China and Japan pavilions).

Green roofs or façades are not enough to ensure the reduction of environmental impact of a building, since the biggest part of energy used in building is used during the construction phase. The use of green energy and the attention to architectural details are surely praiseworthy and represent a key to success in the zero-emission goal, but the primary focus of the designers must be put on the emissions produced on the construction sites and during the production of the materials.

The realized buildings give a strong perception of green and sustainable construction, evocating these concepts, but "perceived architecture" and "real architecture" are deeply different. The realization of a perceived architecture that communicates the importance of eco-sustainability is surely important, but it does not guarantee the achievement of guidelines' goals.

It feels like someway the lack of time for designing and the necessity to improve a way to make to construction fast and easy to dismount made some designers forget the principal theme of Expo 2015. Data showed the massive use of artificial and heavy-weight materials, while the opposite was required.

The introduction of a new way of thinking and designing worrying about eco-sustainability is a revolution and, as a revolution, it needs a radical change in the approach to design itself.

The nations spoke of sustainable constructions in a common language, but this language must grow up and reach a new awareness and sensitivity. This Expo 2015 should have been a great chance to start speaking in this aware and sensitive language, but actually it looks just like a lost opportunity to fully explore this theme, although at the same time probably Expo has successfully transmitted to the public of non-experts the concept of Sustainable Architecture.

\section{References}

1. Guidelines Green Procurement, Expo 2015, 2015, retrieved from http://www.expo2015.org/archive/en/learn-more/sus tainability/guidelines-for-participants.html

2. Guidelines Sustainable Solutions, Expo 2015, 2015, retrieved from http://www.expo2015.org/archive/en/learn-more/sus tainability/guidelines-for-participants.html

3. L. Starke, E. Assadourian, T. Prugh (Eds.), State of the world 2013 is sustainability still possible? Island Press, Washington, DC, 2013

4. S. Guy, G. Farmer, Reinterpreting sustainable architecture: the place of technology. J. Arch. Edu. 54, 140-148 (2001)

5. W. Zhe, Z. Li, S. Jing, On the beauty of green Expo architecture and sustainable development: taking "China pavilion" as an example, Procedia Eng. 21, 163-167 (2011)

6. M. Gębarowski, The idea of sustainable development in national performances by participants of Expo 2015, Zeszyty Naukowe Wyższej Szkoły Ekonomiczno-Społecznej w Ostrołęce 21, 323-338 (2016)

7. R. Milford, Re-use without melting: scrap re-use potential and emissions savings, Mech. Eng. 17 (1989)

Cite this article as: A. La Tegola, F. Longo and A. Lanzilotti: The pavilions of Expo 2015 in Milan, as a privileged observatory about the concept of sustainable construction in all languages of the world. Sust. Build. 4, 1 (2019). 